\title{
Morphological and Structural Investigations on Iron Borosilicate Glasses
}

\author{
Gomaa El-Damrawi, Abdel Meguid Hassan, Sammer El-Jadal \\ Glass Research Group, Physics Department, Faculty of Science, Mansoura University, Mansoura, Egypt \\ Email: gomaaeldamrawi@gmail.com
}

How to cite this paper: El-Damrawi, G. Hassan, A.M. and El-Jadal, S. (2017) Morphological and Structural Investigations on Iron Borosilicate Glasses. New Journal of Glass and Ceramics, 7, 13-21. https://doi.org/10.4236/njgc.2017.72002

Received: November 16, 2016

Accepted: April 25, 2017

Published: April 28, 2017

Copyright ( 92017 by authors and Scientific Research Publishing Inc. This work is licensed under the Creative Commons Attribution International License (CC BY 4.0).

http://creativecommons.org/licenses/by/4.0/

\section{(c) (i) Open Access}

\begin{abstract}
Borosilicate glasses and glass ceramics in the system $30 \mathrm{Na}_{2} \mathrm{O}-2 \mathrm{Al}_{2} \mathrm{O}_{3}-25 \mathrm{SiO}_{2}-\mathrm{xFe}_{2} \mathrm{O}_{3}(43-\mathrm{x}) \mathrm{B}_{2} \mathrm{O}_{3}$ ( $\mathrm{x}=0$ - 20 mol\%) have been prepared and studied by distinguished techniques. X-ray diffraction (XRD), transmission electron microscope (TEM), electron diffraction pattern (EDP) and SEM experiments are applied to explore the induced structural changes. Nanometer-sized species of polycrystalline structure are formed particularly in low $\mathrm{Fe}_{2} \mathrm{O}_{3}$ containing glasses. The size of the crystallites is found to depend on $\mathrm{Fe}_{2} \mathrm{O}_{3}$ concentrations. It is ranged from 10 to 33 nanometers. Structurally, these materials are suggested to contain different components, crystalline component and an interfacial component which situated between the crystallized domains. Presence of these components affects the atomic arrangement without short- or long-range order. An intermediate range ordered structure is dominant in glass ceramics of $\mathrm{Fe}_{2} \mathrm{O}_{3}<8 \mathrm{~mol} \%$. Less ordered structure is dominated in glasses of higher $\mathrm{Fe}_{2} \mathrm{O}_{3}$ concentration, since more disordered structure of lower size is present. These structural changes are found to be connected with the role of $\mathrm{Fe}_{2} \mathrm{O}_{3}$ and $\mathrm{Na}_{2} \mathrm{O}$ in glasses. $\mathrm{Na}_{2} \mathrm{O}$ is the strong glass modifier in the studied composition region, while $\mathrm{Fe}_{2} \mathrm{O}_{3}$ is consumed also as a modifier in composition of $<8 \mathrm{~mol} \%$. Glass forming character of $\mathrm{Fe}_{2} \mathrm{O}_{3}$ is mainly dominant in the composition region of higher iron oxide concentration (8 - $20 \mathrm{~mol} \%)$.
\end{abstract}

\section{Keywords}

Borosilicate, Morphology, Glass Ordered Structure, Clusters

\section{Introduction}

Glasses and glass ceramics containing metal oxide have a wide variety in most of industrial and technical applications [1] [2] [3]. However, a growing development of technical technology requires specific types of glasses. For instance, spe- 
cific composition from borosilicate glasses has been devoted as special sealants for Molten Carbonate Fuel Cells (MCFC) [2] [3]. Both academic and technical advantages of borosilicate glasses have been correlated with some specific structural studies which were carried out on these materials. Powerful techniques such as spinning NMR and FTIR spectroscopy [4] [5] [6] [7] are the most suitable methods applied to get a quantitative analysis of different structural units forming a network structure of the tested material.

The changes in microstructure of borosilicate glasses were found to depend on their own building species such $\mathrm{Q}^{\mathrm{n}}\left[\mathrm{SiO}_{4}\right],\left[\mathrm{BO}_{3}\right]$ and $\left[\mathrm{BO}_{4}\right]$ units in borosilicate network. In miscibility region of borate and silicate network structure, the oxygen atoms can be bonded to boron and silicon atoms and have a $\mathrm{Na}^{+}$ion as a charge compensator [4] [6]. In such situation, phase separation can't be considered and both the borate and silicate network are both mixed and modified by $\mathrm{Na}_{2} \mathrm{O}$. On the other hand, in the immiscibility region, phase separation is the dominant feature and has a significant influence on the structure and properties of the materials [1] [2] [3] [4]. The properties in phase separating glasses strongly depend on the thermal history and material composition [6] [8] [9] [10]. In borosilicate glasses, at least two phases are separated in certain composition regions. The original glassy phase tends to separate into a silica-rich phase, and a borate-rich one upon changing glass composition.

The arrangement of the modifier oxide between silicate and borate network depends on two structural factors namely $\mathrm{R}$ and $\mathrm{K}$. Generally $\mathrm{R}$ is the ratios of $\mathrm{Na}_{2} \mathrm{O} / \mathrm{B}_{2} \mathrm{O}_{3}$ and $\mathrm{K}$ is the ratio of $\mathrm{SiO}_{2} / \mathrm{B}_{2} \mathrm{O}_{3}$ [4] [6]. For example, for small value of $\mathrm{R}(<0.5)$ and higher $\mathrm{K}$, separated phases can take place. Otherwise, the structural species of silicate and borate units are mixed.

The present paper aims to make use of our recent published work which based on NMR and FTIR spectroscopy [4] to shed more light on detailed structure of borosilicate glasses containing iron oxide. In this regard, XRD, ED spectroscopy, SEM and TEM are applied to give information on different range ordered structure which may be affected by changing $\mathrm{Fe}_{2} \mathrm{O}_{3}$ concentration in the studied glasses.

\section{Experimental Methods}

\subsection{Sample Preparation}

The glasses were prepared from raw materials graded $\mathrm{SiO}_{2}, \mathrm{H}_{3} \mathrm{BO}_{3}, \mathrm{Na}_{2} \mathrm{CO}_{3}$, $\mathrm{Al}_{2} \mathrm{O}_{3}$ and $\mathrm{Fe}_{2} \mathrm{O}_{3}$. The sodium borosilicate glasses were prepared by melting batches in alumna crucibles at a temperature ranging from $1250^{\circ} \mathrm{C}$ to $1520^{\circ} \mathrm{C}$ depending on composition. Then the melt was frequently swirled to make the material free from air bubbles and to enhance homogeneity of the melt. Then, the melt has been quenched by pouring it over a stainless steel plate.

\subsection{XRD Measurement}

XRD measurements were carried out using a Brucker Axs-D8 technique. CuKa radiation source $(\lambda \mathrm{CuK} \alpha=0.1540600 \mathrm{~nm})$ has been utalized. Data was accumu- 
lated steeply with an interval of $0.02^{\circ}$, over a $2 \theta$ range of $4^{\circ}-65^{\circ}$ using a dwell time of 0.4 seconds. The obtained experimental patterns were compared to standards compiled by Joint Committee on Powder Diffraction and Standards (JCDPS).

\subsection{Transmission Electron Microscopy (TEM)}

Transmission Electron Microscopy (TEM) is a common technique used to evaluate the shape, size, and morphology of the bulk of the material. TEM investigations were carried out using a JEOL-JEM-2100, with an acceleration voltage of $200 \mathrm{kV}$. During this technique, a high energy beam of electrons is transmitted through a very thin specimen, causing interactions between the electrons and the atoms and producing the TEM images.

\subsection{SEM Micrographs and EDX Spectra}

SEM micrograph were obtained with a JEOL JSM 6400 scanning electron microscope equipped with a Link analytical system. The electron energy used was $20 \mathrm{keV}$. The SEM and EDX analysis were carried out for some selected samples.

\section{Results and Discussion}

\subsection{XRD Studies}

The structure of some of the investigated glasses may offers neither long-range order (like crystals) nor short-range order like glasses. It possess polycrystalline structure with intermediate range order. XRD patterns of some selected glass compositions are presented in Figure 1. Weak diffraction peaks are appeared in

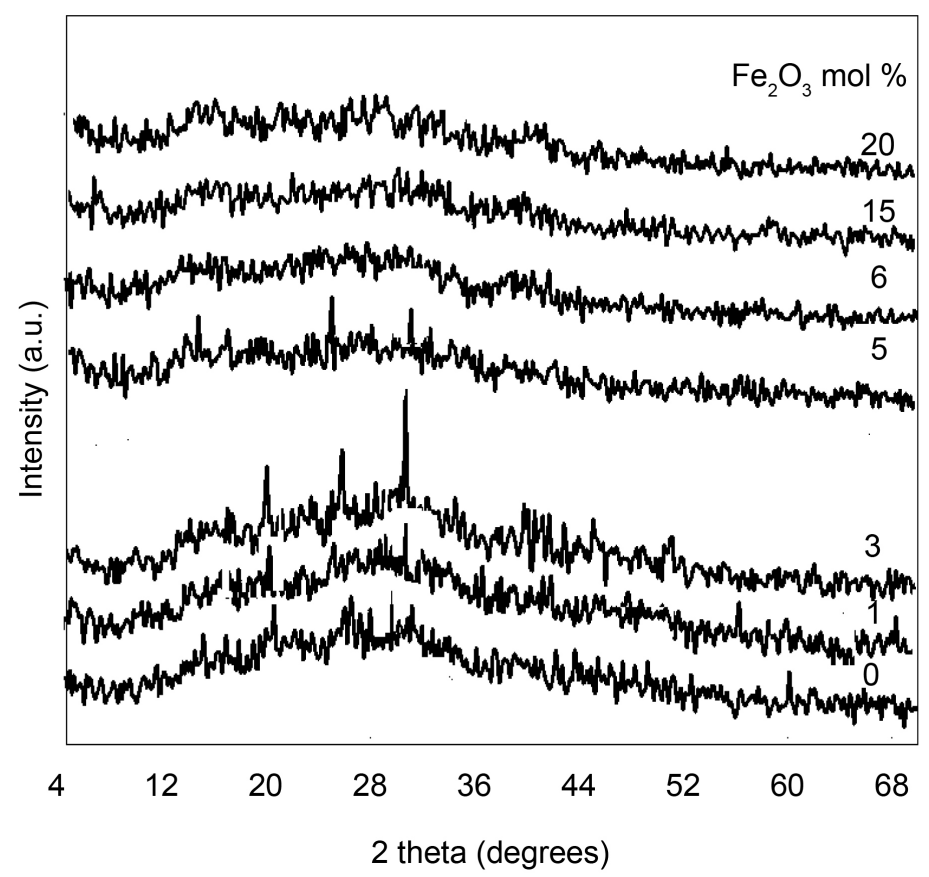

Figure 1. XRD pattern of borosilicate glasses containing different $\mathrm{Fe}_{2} \mathrm{O}_{3}$ concentrations. 
the patterns of the glass containing $0,1,3$ and $5 \mathrm{~mol} \% \mathrm{Fe}_{2} \mathrm{O}_{3}$. These diffractions are centered at $2 \theta=18.5,25.2,30$, and 60 degree, revealing precipitation of some ordered $\mathrm{Na}_{2} \mathrm{SiO}_{3}$ species in these glasses [Card No. 16-818]. Formation of polycrystalline cluster from $\mathrm{Na}_{2} \mathrm{SiO}_{3}$ is accessible in these glasses, since network is enriched with $\mathrm{NBO}$ atoms. The total modifier content from both $\mathrm{Na}_{2} \mathrm{O}$ and $\mathrm{Fe}_{2} \mathrm{O}_{3}$ is extremely high in these glasses [4]. This leads to formation of high concentration from non-bridging bonds (NBO) in the silicate network [9]. On the other hand, maximum $\mathrm{BO}_{4}$ groups in borate network are also considered. This was evidenced from NMR data of the same selected glasses [4].

In initial glasses $\left(0-5 \mathrm{~mol} \% \mathrm{Fe}_{2} \mathrm{O}_{3}\right)$, part of modifier oxide $\left(\mathrm{Na}_{2} \mathrm{O}\right.$ and $\left.\mathrm{Fe}_{2} \mathrm{O}_{3}\right)$ is consumed to produce $\mathrm{NBO}$ in silicate, the other portion can be consumed to modify the borate network and the rest is distributed as accumulated polycrystalline clustered species containing $\mathrm{Na}$ and $\mathrm{Fe}$ ions. The extra modifier oxide are forced to form some nano-size crystallites or clusters from its own. As a direct result, $\mathrm{Na}_{2} \mathrm{SiO}_{3}$ are the main species which are simply to be formed. The angular position of the diffraction lines in the XRD peaks closely match the $\mathrm{Na}_{2} \mathrm{SiO}$ [card nu.78-1713C]. On the other hand, diffraction peaks disappear for all glasses of $\mathrm{Fe}_{2} \mathrm{O}_{3}>5 \mathrm{~mol} \%$. Only a broad hump arises revealing of less ordered glassy matrix containing poly crystalline species of extra small size. As can be seen from Figure 1 a broad band, free from sharp diffraction, in samples of higher $\mathrm{Fe}_{2} \mathrm{O}_{3}$ concentration (6-20 mol\%) is the dominant. These features reflect less ordered structure of investigated glasses [11]-[13].

Absence of sharp diffraction peaks in $\mathrm{Fe}_{2} \mathrm{O}_{3}$ rich glasses reveals that $\mathrm{Fe}_{2} \mathrm{O}_{3}$ inter the network as glass former [4] [10]. As the content of $\mathrm{Fe}_{2} \mathrm{O}_{3}$ increases the concentration of total modifier and NBO ion decreases [4]. As a consequence, the concentration of the well-formed ordered $\mathrm{Na}_{2} \mathrm{SiO}_{3}$ should be decreased. The decrease in $\mathrm{Na}_{2} \mathrm{SiO}_{3}$ concentration is considered as a result of formation of $\mathrm{FeO}_{4}$ units as a former species. Formation of such units required more modifier which would be withdrawn from both silicate and borate network. As a result the modified silicate units $\left(\mathrm{Na}_{2} \mathrm{SiO}_{3}\right)$ should be reduced.

\subsection{Morphology and Phase Analysis}

\subsubsection{TEM and EDP}

Evidences based on XRD data are in a good agreement with that obtained from TEM and EDP, Figures 2-6. Both confirmed that well-formed structural species are constructed in its amorphous state in glasses of high concentration $\mathrm{Fe}_{2} \mathrm{O}_{3}(\geq$ $6 \mathrm{~mol} \%$ ). Samples of $10 \& 20 \mathrm{~mol} \% \mathrm{Fe}_{2} \mathrm{O}_{3}$ are presented as examples, Figure 5 and Figure 6. On the other hand, at lower $\mathrm{Fe}_{2} \mathrm{O}_{3}$ contents, sub crystallized species are formed within the glassy state. The crystal size and morphology of the crystalline phases is shown to depend on the glass composition, particularly on $\mathrm{Fe}_{2} \mathrm{O}_{3}$ concentration. The size of well-formed ordered species in poor iron glass ( $1 \mathrm{~mol} \% \mathrm{Fe}_{2} \mathrm{O}_{3}$ ) is ranged from 21 to $37 \mathrm{~nm}$ as listed in TEM micrograph Figure 1. While the size is decreased upon more addition of $\mathrm{Fe}_{2} \mathrm{O}_{3}$, since it lies in the region of $7-10 \mathrm{~nm}$. The decrease of cluster size with increasing $\mathrm{Fe}_{2} \mathrm{O}_{3}$ content 

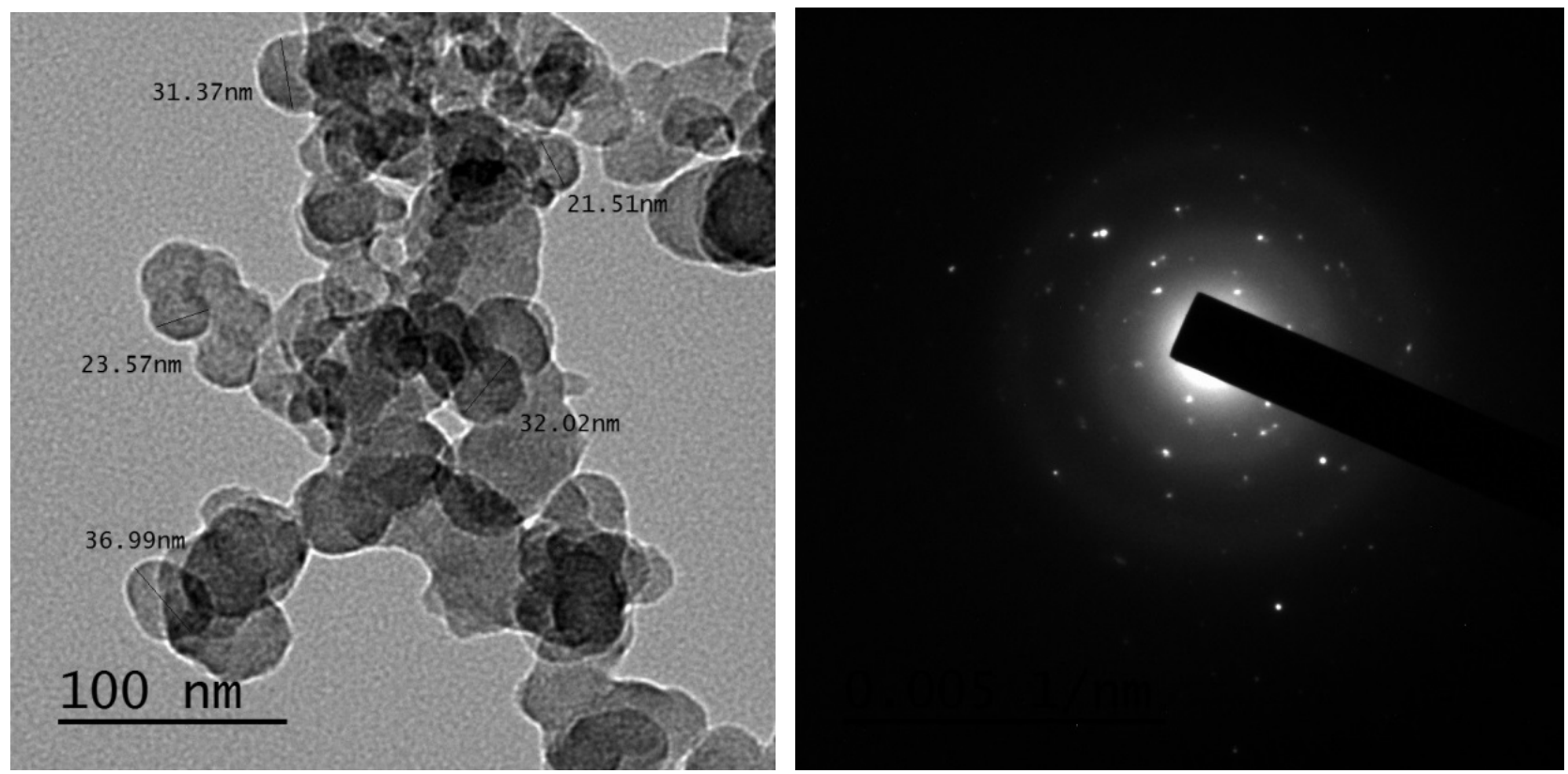

Figure 2. TEM and EDP of glass containing $1 \mathrm{~mol} \% \mathrm{Fe}_{2} \mathrm{O}_{3}$.
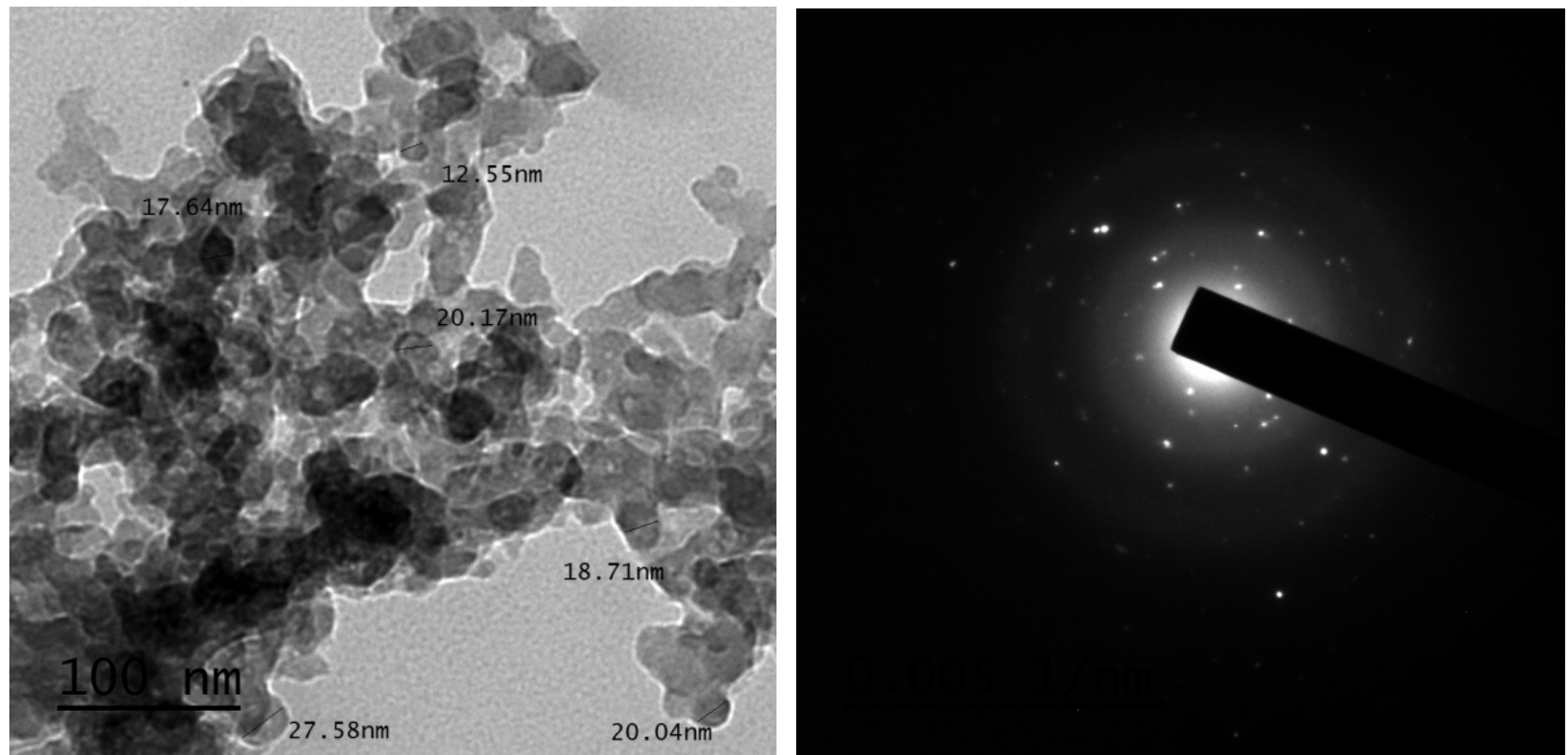

Figure 3. TEM and EDP of glass containing $3 \mathrm{~mol} \mathrm{Fe} \mathrm{O}_{3}$.

confirms that iron has high ability to withdraw NBO from the silicate and plays the role of a glass former [4]. This would accompanied by a decreasing size and the content of sodium silicate clustered phases.

As shown in Figure 2 and Figure 3, micro-crystallized clustered species are clearly evidenced in glasses containing 1 and 3 mol\% $\mathrm{Fe}_{2} \mathrm{O}_{3}$, since iron and sodium oxide can play a role of modifier [4]. On the other hand, the concentration of the aggregated clustered species is shown to decrease with increasing $\mathrm{Fe}_{2} \mathrm{O}_{3}$ content, see Figures 4-6. In such situation, $\mathrm{Fe}_{2} \mathrm{O}_{3}$ has the ability to withdraw more and more $\mathrm{NBO}$ and $\mathrm{Na}$ ions from the silicate network which in turns 

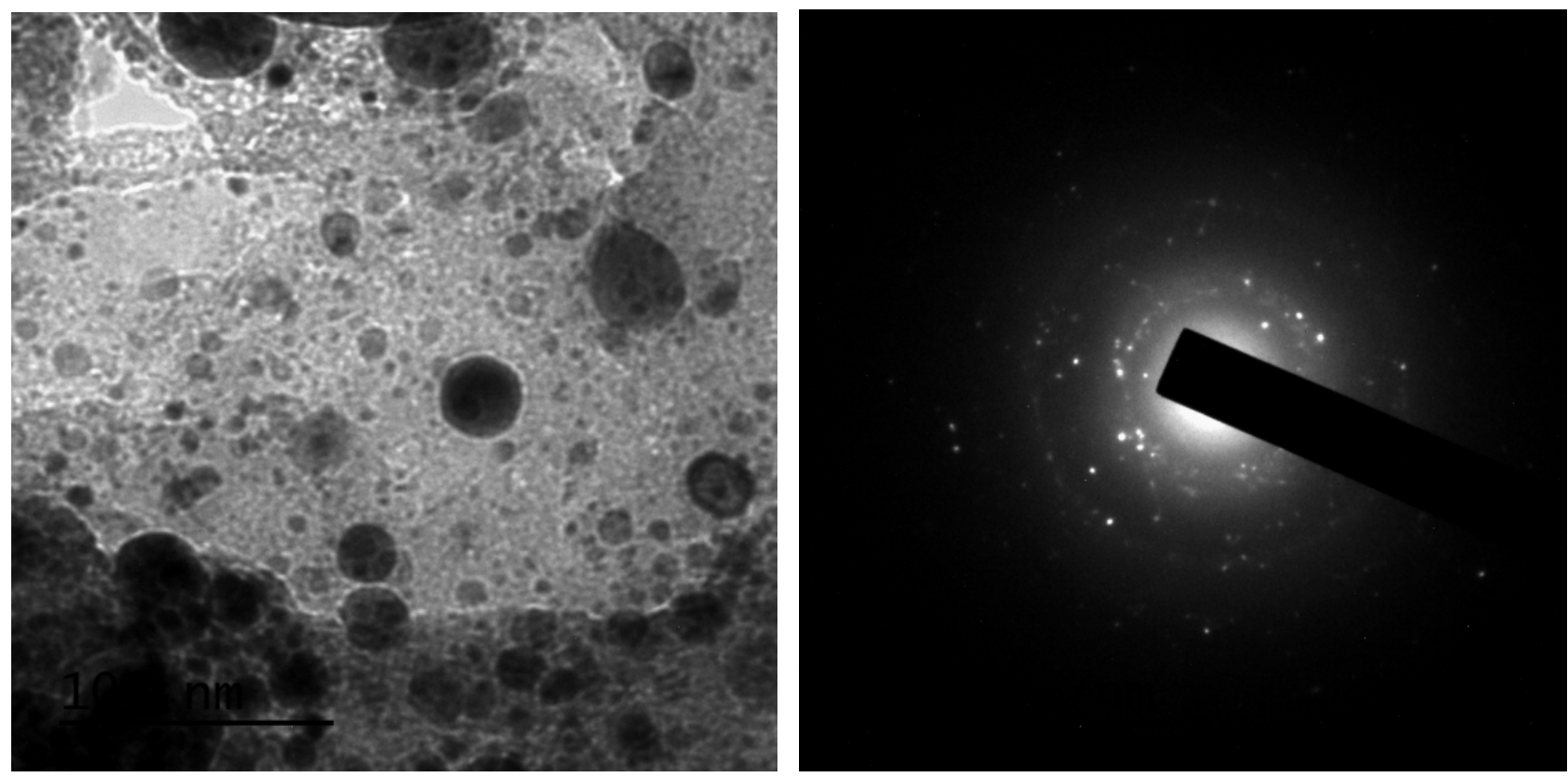

Figure 4. TEM and EDP of glass containing $6 \mathrm{~mol} \mathrm{Fe}_{2} \mathrm{O}_{3}$.
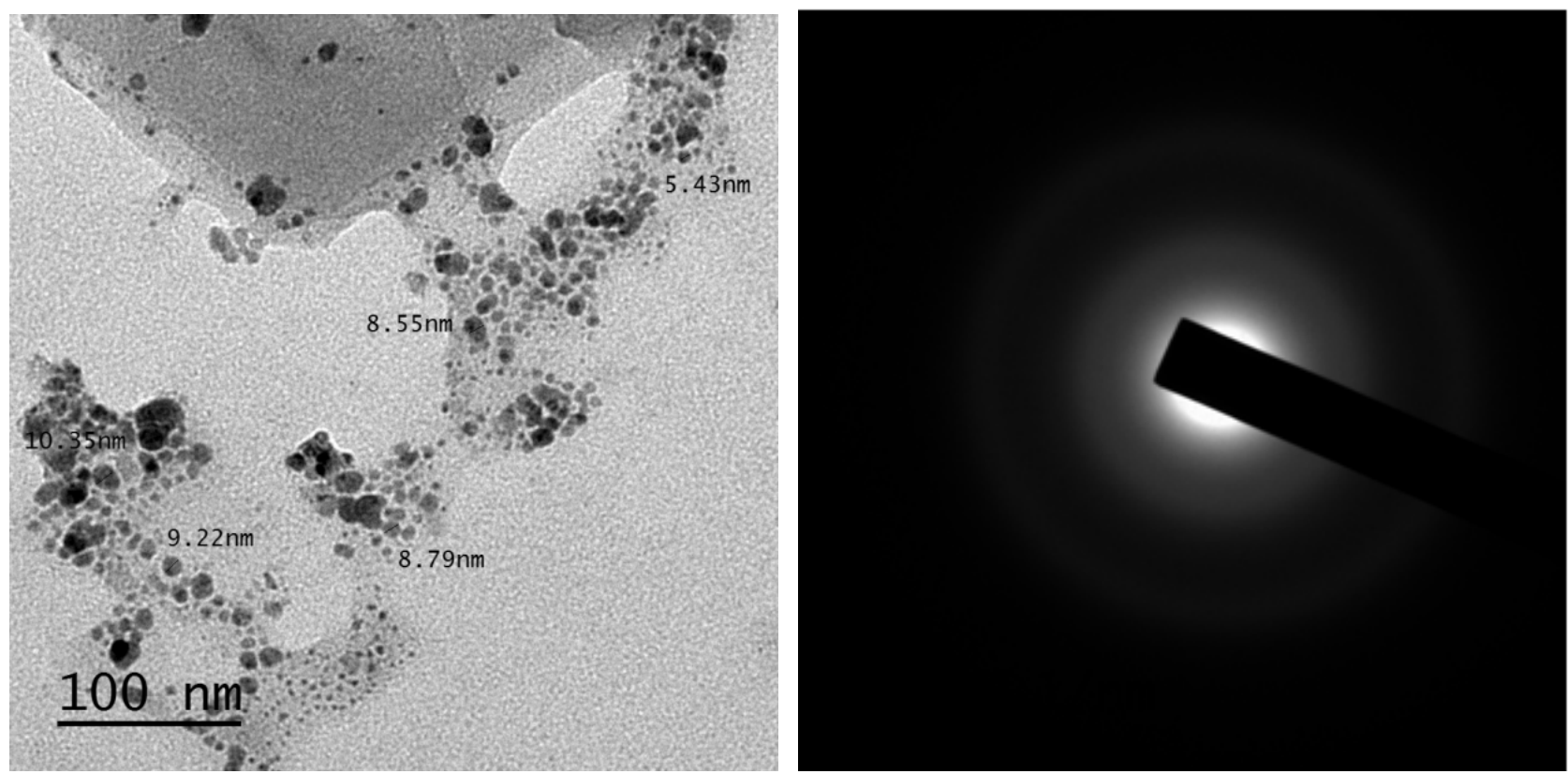

Figure 5. TEM and EDP of glass containing $10 \mathrm{~mol} \mathrm{Fe}_{2} \mathrm{O}_{3}$.

reduces the content and the size of the well-formed clusters.

It can be observed from TEM and EDP that the disorder of the aggregated species increases with increasing $\mathrm{Fe}_{2} \mathrm{O}_{3}$ concentration. The interconnection between different species drops down on further increase in $\mathrm{Fe}_{2} \mathrm{O}_{3}$ concentration and becomes almost indistinguishable from the background at around 20 mol\% $\% \mathrm{Fe}_{2} \mathrm{O}_{3}$, see Figure 6 .

\subsubsection{SEM and EDEX Analysis}

Same observation is observed from SEM micrographs Figure 7 and Figure 8, 

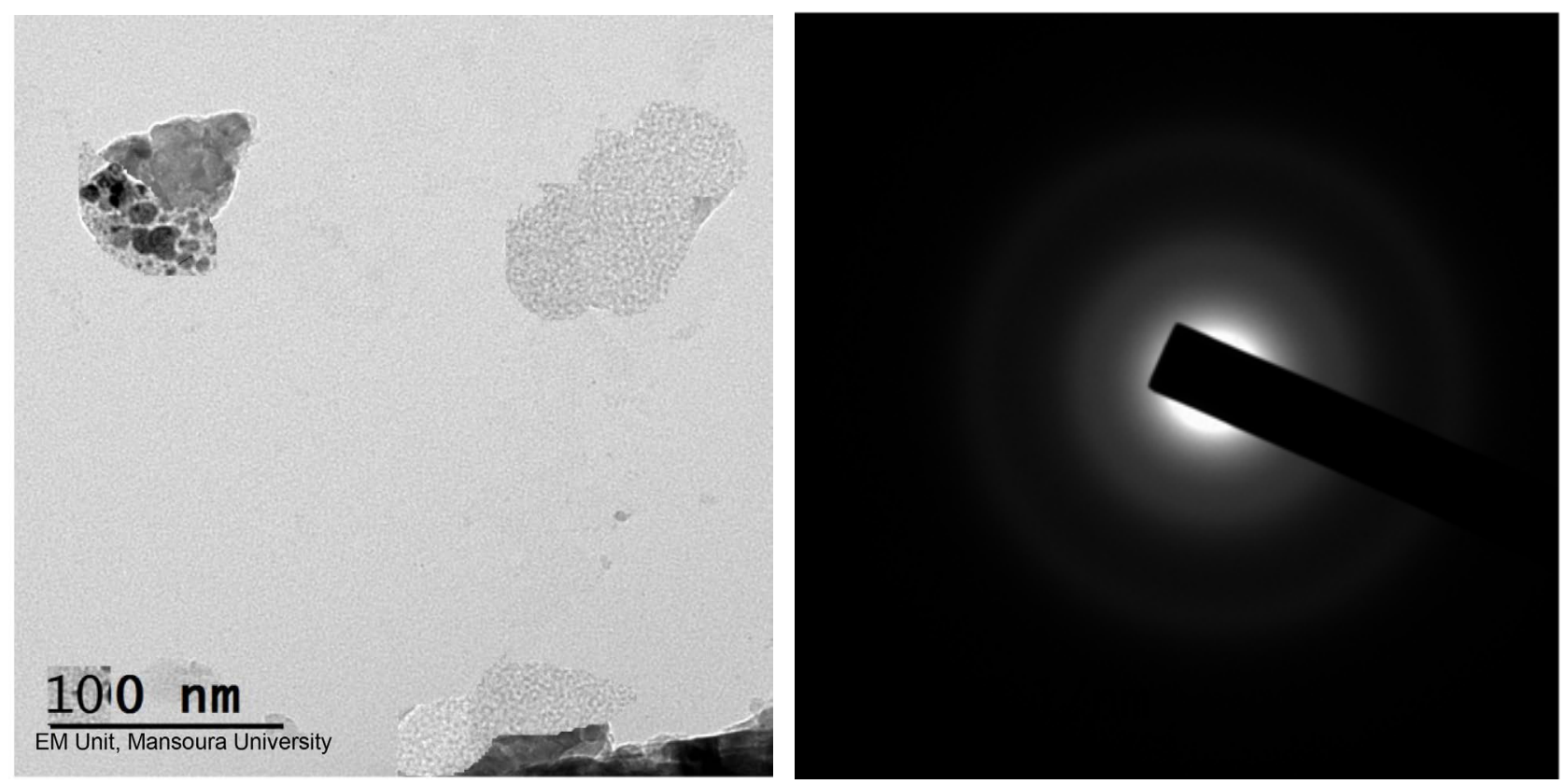

Figure 6. TEM and EDP of glass containing $20 \mathrm{~mol} \% \mathrm{Fe}_{2} \mathrm{O}_{3}$.
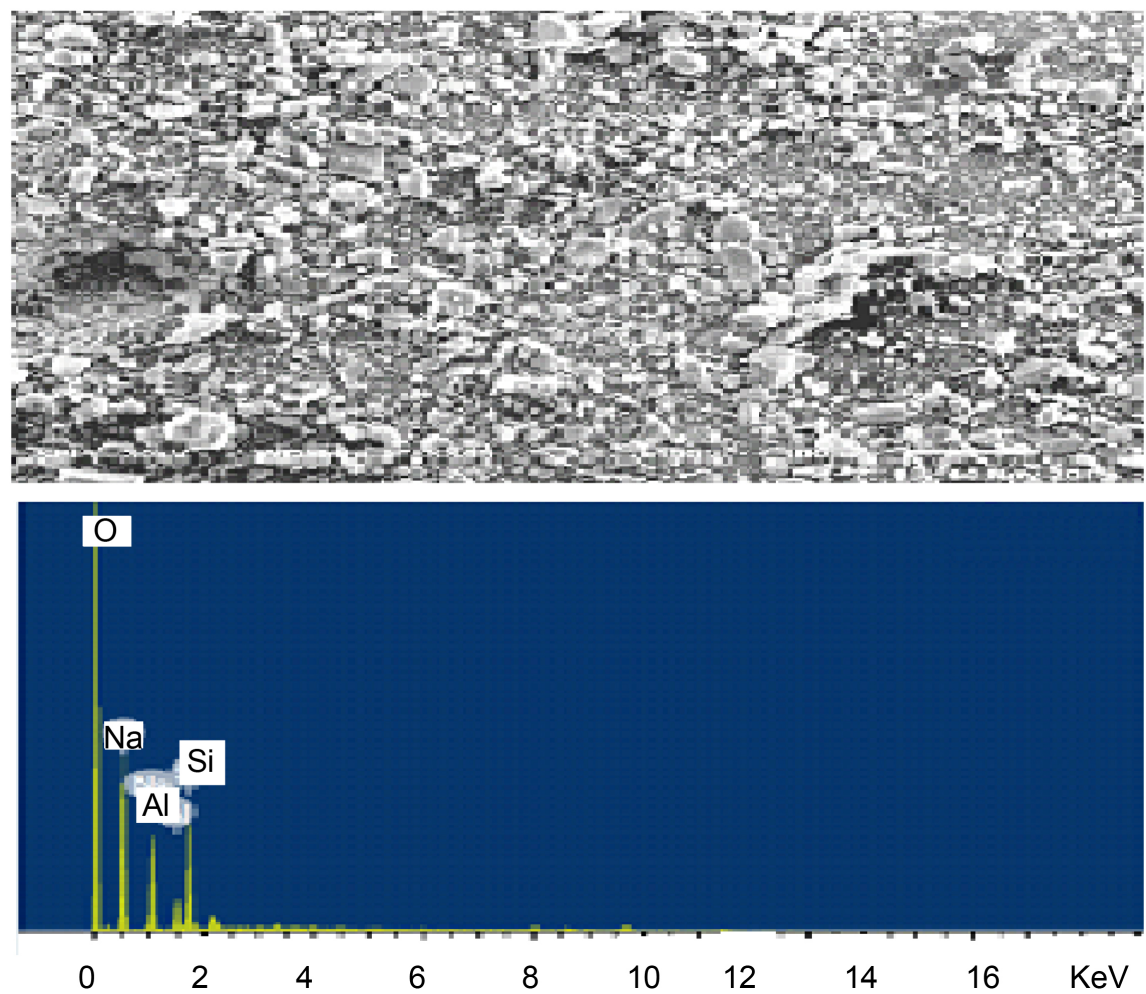

Figure 7. SEM and EDEX spectra of glass containing $3 \mathrm{~mol} \% \mathrm{Fe}_{2} \mathrm{O}_{3}$.

The concentration of the aggregated species is shown to be more higher in sample containing $3 \mathrm{~mol} \% \mathrm{Fe}_{2} \mathrm{O}_{3}$ (Figure 7) when it compared with sample of higher iron oxide Figure 8. This observation supports that both concentration of NBO and the modifier in the silicate network are reduced. $\mathrm{Fe}_{2} \mathrm{O}_{3}$ changes its role from modifier to former to form $\mathrm{FeO}_{4}$ groups. As a result the size and concentration 

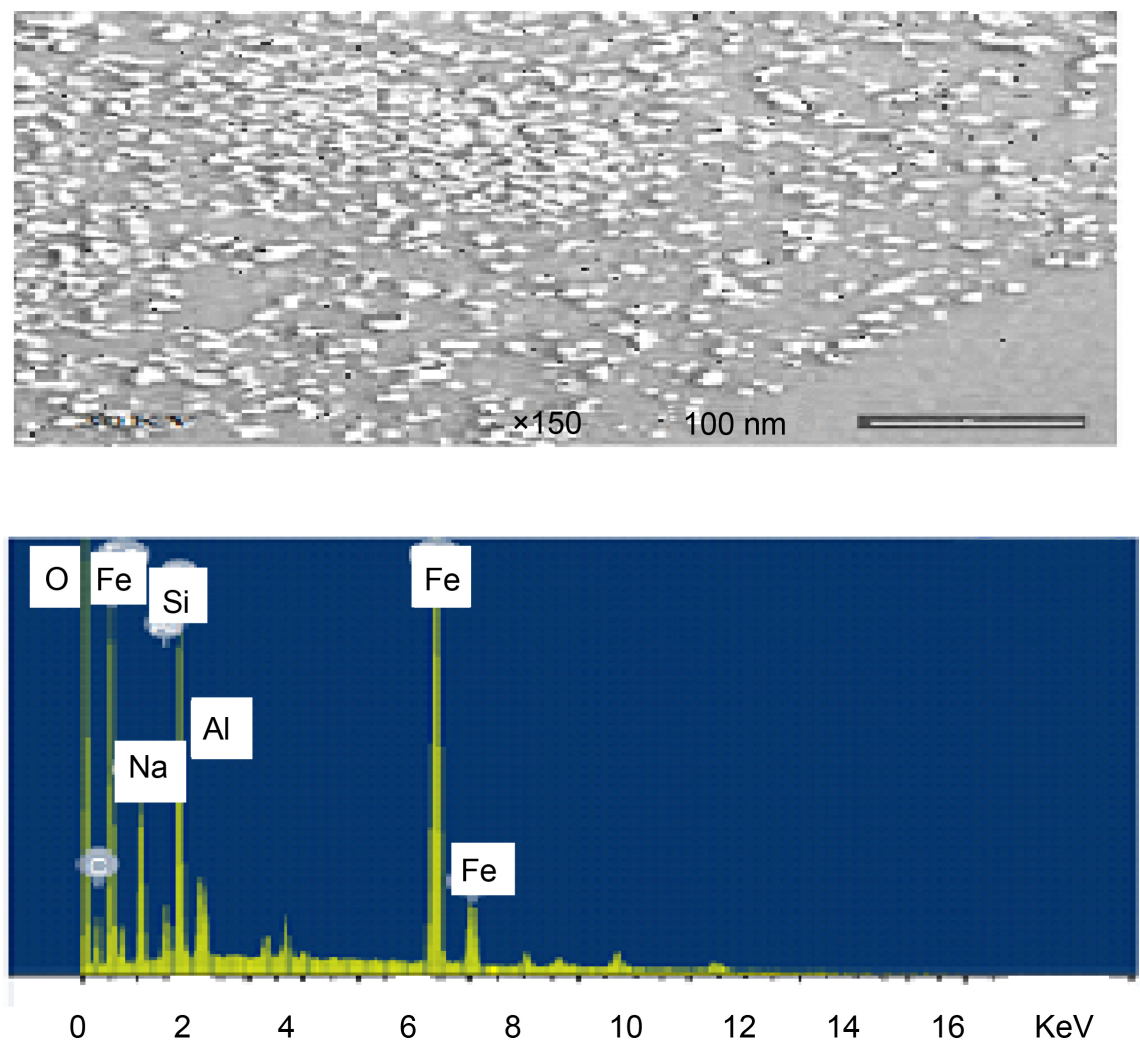

Figure 8. SEM and EDEX spectra of glass containing $10 \mathrm{~mol} \% \mathrm{Fe}_{2} \mathrm{O}_{3}$.

of polycrystalline species $\left(\mathrm{Na}_{2} \mathrm{SiO}_{3}\right)$ should be decreased as presented from both SEM and TEM micrographs.

Elemental analysis of samples containing 3 and $10 \mathrm{~mol} \% \mathrm{Fe}_{2} \mathrm{O}_{3}$ has been also done using EDEX spectroscopy. The spectra of glass of low $\mathrm{Fe}_{2} \mathrm{O}_{3}$ content ( 3 mol\%) contains only $\mathrm{Na}, \mathrm{Si}$ and $\mathrm{O}$ elements, Figure 7. There is no any evidence for presence of $\mathrm{Fe}$ in the crystalized phase. This means that $\left(\mathrm{Na}_{2} \mathrm{SiO}_{3}\right)$ clustered phase is the dominant. On the other hand, glasses of higher $\mathrm{Fe}_{2} \mathrm{O}_{3}(10 \mathrm{~mol} \%)$, see Figure 8 presented several Fe EDEX spectral lines which are highly resolved. In addition, spectrum of $\mathrm{Na}, \mathrm{O}$ and $\mathrm{Si}$ are also present. The phase in such case is enriched with $\mathrm{FeO}_{4}$ groups which in turns result in increasing the disorder of the $\left(\mathrm{Na}_{2} \mathrm{SiO}_{3}\right)$ phases. Presence of $\mathrm{FeO}_{4}$ groups in in sodium silicate phase causes mismatching between units which form the glass network. As a result, amorphous structure in such a case is the dominant feature of glass of containing high $\mathrm{Fe}_{2} \mathrm{O}_{3}$ concentration. This conclusion is agreed to great extend with that obtained from both XRD and TEM results which discussed above.

\section{Conclusion}

$\mathrm{X}$-ray diffraction (XRD), transmission electron microscope (TEM), electron diffraction pattern (EDP) and SEM experiments are applied to analyze the structural changes. Species of polycrystalline structure are formed in low $\mathrm{Fe}_{2} \mathrm{O}_{3}$ containing glasses. The obtained size is ranged from 10 to 33 nanometers. An intermediate range ordered structure is dominant in glass ceramics of $\mathrm{Fe}_{2} \mathrm{O}_{3}<8$ 
mol\%. Less ordered structure is a feature of glasses of higher $\mathrm{Fe}_{2} \mathrm{O}_{3}$ concentration. The type of range order is found to be connected with the role of $\mathrm{Fe}_{2} \mathrm{O}_{3}$ and $\mathrm{Na}_{2} \mathrm{O}$ in glasses. $\mathrm{Na}_{2} \mathrm{O}$ is the strong glass modifier in the studied composition region, while $\mathrm{Fe}_{2} \mathrm{O}_{3}$ is consumed also as a modifier in composition of $<8 \mathrm{~mol} \%$. $\mathrm{Fe}_{2} \mathrm{O}_{3}$ is consumed as a network former in the composition region of higher iron oxide concentration ( $\geq 8 \mathrm{~mol} \%$ ).

\section{References}

[1] El damrawi, G., Doweidar, H., Kamal, H. and Dawood, A. (2014) Microstructure and in Vitro Bioactivity of Metal Substituted Hydroxyapatite. British Journal of Applied Science and Technology, 15, 1-12.

[2] Pascual, M.J., Duran, A. and Pascual, L. (2002) Viscosity and Thermal Properties of Two Series of Glasses in the System $\mathrm{R}_{2} \mathrm{O}-\mathrm{B}_{2} \mathrm{O}_{3}-\mathrm{SiO} 2, \mathrm{R}=\mathrm{Li}, \mathrm{K}, \mathrm{Na}$. Physics and Chemistry of Glasses, 43, 25-31.

[3] Pascual, M.J., Duran, A. and Pascual, L. (2002) Sintering Process of Glasses in the System $\mathrm{Na}_{2} \mathrm{O}-\mathrm{B}_{2} \mathrm{O}_{3}-\mathrm{SiO}_{2}$. Journal of Non-Crystalline Solids, 306, 58.

[4] El-Damraei, G., Hassan, A.K., Ramadan, R. and El-Jadal, S. ((2016) Nuclear Magnetic Resonance and FTIR Structural Studies on Borosilicate Glasses Containing Iron Oxide. New Journal of Glass and Ceramics, 6, 47-56. https://doi.org/10.4236/njgc.2016.64006

[5] El-Damrawi, G., Müller-Warmuth, W., Doweida, H. and Gohar, I.A. (1993) $1{ }^{1} \mathrm{~B},{ }^{29} \mathrm{Si}$ and ${ }^{27} \mathrm{Al}$ Nuclear Magnetic Resonance Studies of $\mathrm{Na}_{2} \mathrm{O}-\mathrm{Al}_{2} \mathrm{O}_{3}-\mathrm{B}_{2} \mathrm{O}_{3}-\mathrm{SiO}_{2}$ Glasses. Physics and Chemistry of Glasses, 34, 52.

[6] El-Damrawi, G., Müller-Warmuth, W. and Doweidar, H. (1992) Structure and Heat Treatment Effects of Sodium Borosilicate Glasses as Studied by 29Si and 11B NMR. Journal of Non-Crystalline Solids, 146, 137-144.

[7] Mackenzie, K.J.D. and Smith, M.E. (2002) Multinuclear Solid-State Nuclear Magnetic Resonance of Inorganic Materials. Pergaman Materials Series, Vol. 4, Pergamon Press, Oxford, 218.

[8] El Damrawi, G., Hassan, A.K., Kamal, H., Aboelez, M. and Labeeb, S. (2016) Structural Investigations on Na2O-CaO-V2O5-SiO2 Bioglass Ceramics. British Journal of Applied Science \& Technology, 16, 1-9. https://doi.org/10.9734/BJAST/2016/26683

[9] El damrawi, G., Doweidar, H. and Kamal, H. (2013) Structure and Crystallization Behavior of Silicate-Based Bioactive Glasses. Australian Journal of Basic and Applied Science, 7, 573-582.

[10] Muñoz, F., Montagne, L. and Delevoye, L. (2006) Phosphate Speciation in Sodium Borosilicate Glasses Studied by Nuclear Magnetic. Journal of Non-Crystalline Solids, 352, 2958-2968.

[11] Magdas, D.A., Cozar, O., Chis, V., Ardelean, I. and Vedeanuc, N. (2008) The Structural Dual Role of $\mathrm{Fe} 2 \mathrm{O} 3$ in Some Lead-Phosphate Glasses. Vibrational Spectroscopy, 48, 251-254.

[12] Affatigato, M., Feller, S.A., Howes, A.P. and Scales, C.R. (2008) Quantitative Measurement of Q 3 Species in Silicate and Borosilicate Glasses Using Raman Spectroscopy. Journal of Non-Crystalline Solids, 354, 1936-1942.

[13] Parkinson, B.G., Holland, D., Smith, M.E., Larson, C., Doerr, J., Affatigato, M., Feller, S.A., Howes, A.P. and Scales, C.R. (2008) Quantitative Measurement of Q3 Species in Silicate and Borosilicate Glasses Using Raman Spectroscopy. Journal of Non-Crystalline Solids, 354, 1936-1942. 
Submit or recommend next manuscript to SCIRP and we will provide best service for you:

Accepting pre-submission inquiries through Email, Facebook, LinkedIn, Twitter, etc. A wide selection of journals (inclusive of 9 subjects, more than 200 journals)

Providing 24-hour high-quality service

User-friendly online submission system

Fair and swift peer-review system

Efficient typesetting and proofreading procedure

Display of the result of downloads and visits, as well as the number of cited articles Maximum dissemination of your research work

Submit your manuscript at: http://papersubmission.scirp.org/

Or contact njgc@scirp.org 